(C) Telkom University

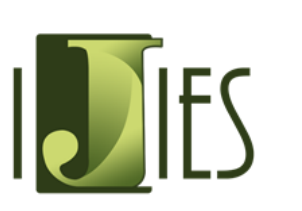
INTERNATIONAL JOURNAL OF INNOVATION IN
ENTERPRISE SYSTEM

Journal homepage: https://ijies.sie.telkomuniversity.ac.id/index.php/IJIES/index

Telkom

e-ISSN: 2580-3050

\title{
How to Create E-Purchasing Based on Open ERP for Integrated Hospital Service System Using QuickStart Methodology
}

\author{
Nesya Irianis ${ }^{1 *}$, Warih Puspitasari ${ }^{2}$, Muhardi Saputra ${ }^{3}$ \\ 1,2,3 Information System Department, Telkom University \\ J1. Telekomunikasi no 1, Bandung, 40257, INDONESIA \\ *nesyairianis14@gmail.com
}

\section{ARTICLE INFO}

Article history:

Received 03 June 2020

Accepted 25 July 2020

Published 30 July 2020

\section{Keywords:}

ERP, Odoo, Purchase

Management, QuickStart

Methodology, Health

Industry.

\begin{abstract}
A B S T R A C T
In this research, the researcher carries out the health Industry of public hospitals in Indonesia. One of the main processes in company business processes is the purchasing of goods. One of the problems in purchasing is the absence of the system that Integrates business processes between the Inventory Department and the Purchasing Department. Hence, interfere with daily operational in RSUD XYZ like due to notification's update delay of the goods causes unavailability stock in the warehouse, so will affect the late purchase of goods at RSUD XYZ. Odoo is a software of Enterprise Resource Planning opensource used by various types of companies. Odoo provides solutions package for Purchase Management to overcome the problem in the company. The researcher used the QuickStart Methodology to implement ERP systems. Odoo implementation with QuickStart needs through five main stages. The result of this research is the design of a planning model for Enterprise Resource Planning system of purchasing in RSUD XYZ. Moreover, Odoo makes business processes in the RSUD XYZ can be automated with real-time information, this automation and real-time data will support the RSUD XYZ to make better decision in the future.
\end{abstract}

\section{Introduction}

Health Ministry of the Republic of Indonesia noted that the number of hospital in Indonesia increased from 2015 to 2018 [1]. The increased number of hospital in Indonesia are directly connected with the increased number of patients. Based on those data, every hospital must ensure their standard and service's quality that will be given to their patient. In order to support operational activity in the hospital, hospital need to implement the information system that would help them to manage their data and information and also to support them in decision making process. So, with the implementation of information system, hospital can improve the service's quality to their patients.

In this research, researcher carry out public hospital in Indonesia as the object of research. RSUD XYZ is one of the government hospitals in Bandung Regency that was operate from 1996. To execute the daily operational in the hospital, hospital already prepare 18 clinics to serve their patient. Beside of that, to support its 18 clinics, the hospital needs some kind of goods, medicine, and also health equipment and supplies. To ensure that all of those needs are always available, the hospital have to execute purchasing activity periodically. Purchasing activity is buying process of the hospital needs from vendor or suppliers that can fulfill the needs of hospital. RSUD XYZ already categorized their goods that have to be purchase into 2 categories, there are stackable and inventory. The large number of items that must be managed by the hospital often becomes the difficult things that have to be faced by the hospital. The uses of information system that can support data management and also purchasing activity would be the best solution to overcome those problem. 
Based on those problem, the hospital is suitable for implementing Enterprise Resource Planning (ERP) system as the information system that overcome the problem in purchasing activity and data management [2]. Enterprise Resource Planning system integrates all data and information from different department under one centralized database system. Through this system, information flow inside the organization are improved and their process become simplified and standardized and it can be accessed by each user based on their allowed level of access on the system.

Odoo is an open source ERP software that can be customized and configured. Beside of that, Odoo have a purchasing module to support the procurement process inside the organization. So, with implementing Odoo system, hospital can adjust the needs of software as the information system to support the purchasing activity and data management in the daily operational activity. The methodology used in this study is Odoo QuickStart. some stages of the Odoo QuickStart implementation method include kick-off call, analysis, configuration, production, and support [3].

\section{Literature Study}

\subsection{ERP}

Enterprise Resource Planning (ERP) is a system which allow companies to integrate business process across organization and functions, all variant best practices business [4]. The system can collect, save, manage, and analyze transactional data on a company from a variety of different sources to help eliminate data redundancy and duplication. It can help companies in making data-driven decisions [5]. ERP allows people to work faster by managing time as technology solutions that help enterprise resource planning, as well as customize the service to make a profit [6].

\subsection{Open Source ERP Software}

Open source ERP software is the ERP system software that can be used, design, customized and configured without license needed. This ERP system usually can be downloaded and used freely. Besides that, in some cases, the developer usually attaches the program code, so every organization or individual can customize and configure this software based on their needs [7].

\subsection{Odoo}

Odoo is a web application that was build using Phyton, XML, and JavaScript as the programming language and also PostgreSQL as the database. In the history, first-time Odoo named with TinyERP, then in 2009, the name was changed to be OpenERP, and after that OpenERP was developed to be the 8th version and the name also changing to be Odoo [8]. Odoo is one of open source ERP software that able to manage all of the organizations needs such as Human Resource, Accounting, Customer Relationship Management, Warehouse Management, Inventory, and others. This capability allows an organization to improve its efficiency for a business solution [9].

- $\quad$ Purchase Management Module in Odoo

The purchase management module is one of Odoo software module that helps the organization to support the buying activity in their business. This module allows the organization to manage the business process of purchasing flow such as creating Request for Quotation (RFQ), creating Purchase Order (PO), Goods Receipt, Creating Vendor Bills, and the others [10]. There are a few modules that connected with the purchase management module in Odoo software:

1. Inventory Module

Inventory module is integrating with purchase management when the organization needs to receipt the goods and store it into the warehouse.

2. Accounting Module

The accounting module is integrating with purchase management to record every balance sheet as the result of the purchase order process and invoicing or billing process. When the purchase module has been executed buying activity, the accounting module will pay the vendor or supplier.

\subsection{E-Purchasing}

E-Purchasing is an electronic-based procurement method (E-Procurement) [11]. E-Procurement is the procurement process of goods or services that executed using information technology and electronic transaction based on government rules. The goods or services procurement by the electronic transaction often executed by e-tendering and also e-purchasing [12]. 


\subsection{Health Information System}

Health information system is an integrated system of merging data, processing, reporting and using information that is important to improve effective and efficient health services through better management of all preparation of health services [13].

According to Regulation of the Indonesian Minister of Health in 2013, Hospital Management Information System (SIMRS) is a communication information technology system that processes and integrates hospital service process flow in the form of a network of coordination, reporting and administrative procedures to obtain information precisely and accurately, and is part of the health information system. The advantage of implementing SIMRS is to simplify the series of activities in hospitals that are arranged neatly and systematically through computerization so that it impacts on services that are more efficient, fast, easy, and transparent.

Meanwhile, according to the World Health Organization (WHO), an integrated system of data collection, processing, reporting and use of information that is important to improve health services effectively and efficiently through better management at all stages of health services

\section{RESEARCH METHODOLOGY}

\subsection{Conceptual Model}

The conceptual model has three cycles, namely relevance, rigor, and design. Relevance is a cycle that explains what problems occur in research. Rigor is a cycle that explains the basic theory and methods to be carried out in research. Design is a cycle that explains what will be made and evaluation that will be done on research [14]. The conceptual model used in this study is the Hevner model, namely design science research. This model has three cycles, namely relevance, rigor, and design. Relevance is a cycle that explains what problems occur in research

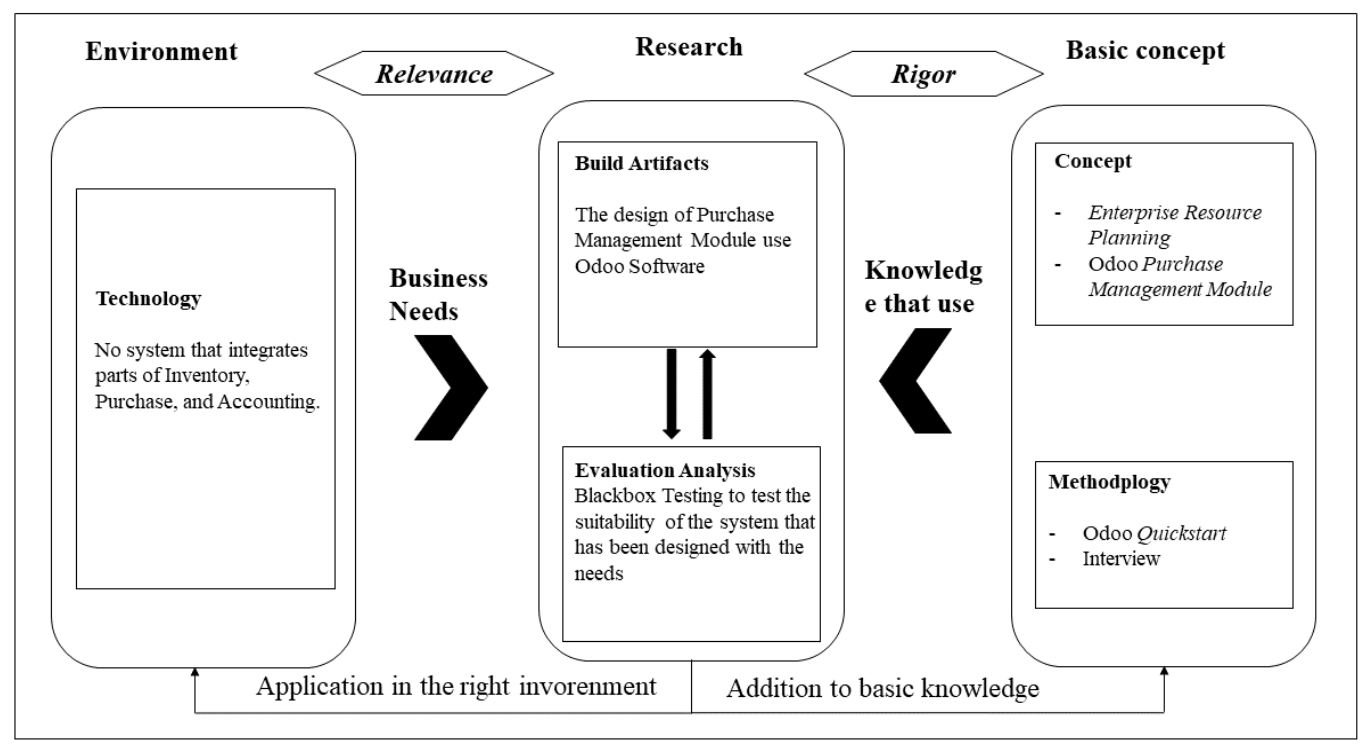

Fig. 1 - Model Conceptual

Figure 1 describes the conceptual model which is divided into 3 areas:

1. Environment

In the research section of the environment, the object of problems in technology is because there is no system that connected the Inventory, Purchase, and Accounting sections.

2. Research

The researchers made an ERP system design using Odoo, especially in the purchasing module.

3. Basic knowledge

The basic knowledge used to design systems in this company is ERP module purchase using the Odoo QuickStart methodology. 


\subsection{Odoo QuickStart Methodology}

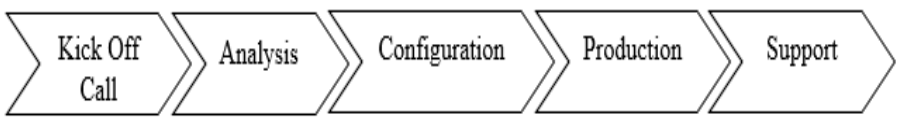

Fig. 2 - QuickStart Methodology Phase

Based on Odoo website, there are 5 stages in the Odoo QuickStart Methodology [15]:

- Kick Off Calls

In this stage, the researcher held a meeting with all of the stakeholders to explain how to execute the implementation process or how the work will be. In this phase researcher also planning the implementation process and decide the finish line of the project.

- Analysis

In this second stage, the researcher analyzing the existing business process and compare it with Odoo business process to identify the fit/gap analysis and also define the organization needs before implementing the software.

- Configuration In this configuration Stage, the researcher defines the organizational structure and the master data design that will be implemented inside the Odoo software.

- Production

Production Stage is the phase where the researcher executes the implementation process based on the configuration design and analysis result in the 2 phases before.

- Support

In this last stage, the researcher doing a performance measurement from the system that has been implemented. The purpose of performance measurement is to execute system testing.

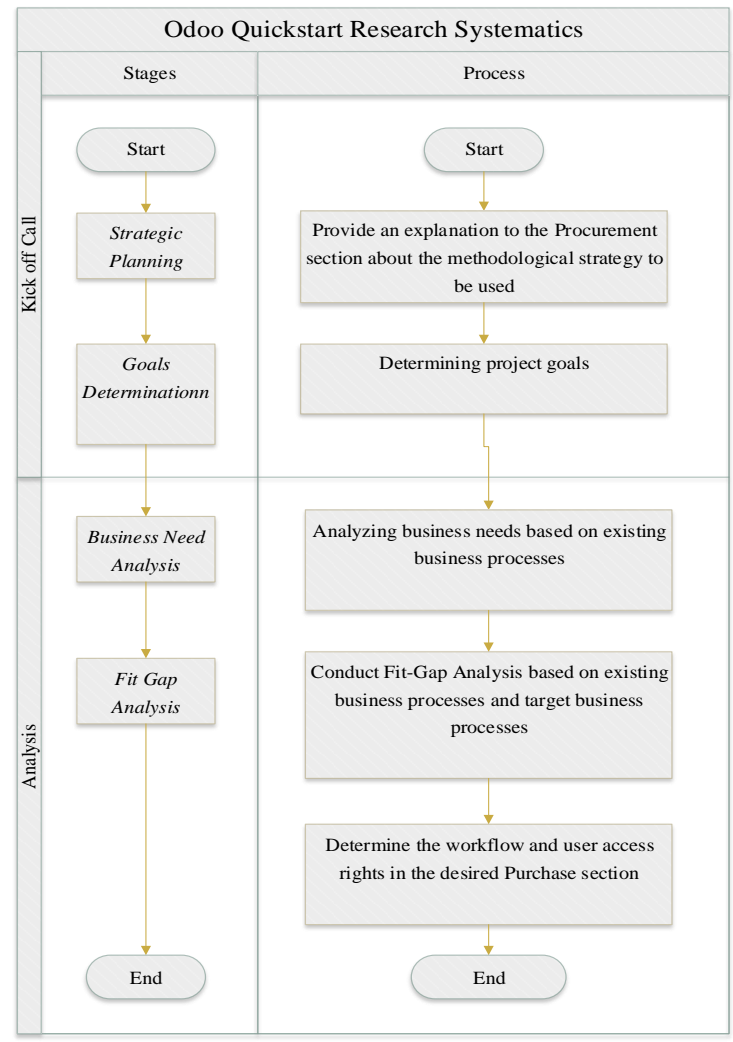

Fig. 3 - Odoo Quickstart Research Systematics

In this research carried out until the second stage, namely analysis and not proceed to the next stage. The figure below explains the systematic research using the QuickStart methodology. 


\section{ANALYSIS AND DESIGN}

\subsection{Kick Off Call}

In this phase, stakeholders related to research are involved in determining the strategies used in planning system design and goals determination.

Table 1 - Strategic Planning

\begin{tabular}{|l|l|l|}
\hline Environment & Development & Basic Science \\
\hline In the purchase of & Developing an ERP Module & Basic Concepts: \\
goods, no system that & Purchasing system with the & - ERP \\
integrated with the & Odoo application & - Purchase \\
Inventory and & & - Odoo Functional \& Technical Resources \\
Accounting. & & Methodology: \\
& & - Odoo QuickStart \\
\hline
\end{tabular}

Table 1 explain about environment of purchasing business process, absence of the system that integrates between Inventory and Accounting. The goals of this research is to design a purchasing module based Odoo using QuickStart methodology.

\subsection{Analysis}

In this phase, analysis business process existing is start from identifying deficiency in the business process to things that need to be added in order to improve business process. Then researcher will be redesigning the business process to make an improvement.

- $\quad$ Fit/Gap Analysis

Gap analysis is used to identify gaps between existing condition and needs or requirement of company to optimize the resource and productivity.

Table 2 - Fit / Gap Analysis

\begin{tabular}{|c|c|c|c|}
\hline Existing Condition & Needs & Fulfillment & Solution \\
\hline $\begin{array}{l}\text { Recording transaction in } \\
\text { procurement and purchase } \\
\text { activity still unintegrated with } \\
\text { inventory and accounting } \\
\text { process because of absence } \\
\text { system and separated database }\end{array}$ & $\begin{array}{l}\text { Integrated } \\
\text { which is connecting all } \\
\text { of business process } \\
\text { with across division } \\
\text { using centralized } \\
\text { database }\end{array}$ & $\mathrm{N}$ & $\begin{array}{l}\text { Centralized database that will } \\
\text { allow every user or division to } \\
\text { access the same data in a real } \\
\text { time }\end{array}$ \\
\hline $\begin{array}{l}\text { Purchasing process is still be } \\
\text { execute manually and there is } \\
\text { no documentation }\end{array}$ & Purchasing history & $\mathrm{P}$ & $\begin{array}{l}\text { With system, request for } \\
\text { quotation will be convert to } \\
\text { purchase order. In purchase } \\
\text { menu there is a purchase } \\
\text { history. }\end{array}$ \\
\hline Absence of vendor data & $\begin{array}{l}\text { Manage vendor data in } \\
\text { system Odoo }\end{array}$ & $\mathrm{P}$ & $\begin{array}{l}\text { Create vendor data in the } \\
\text { vendor menu on the Odoo } \\
\text { System }\end{array}$ \\
\hline
\end{tabular}

Note:

- $\quad \mathrm{P}($ Partial): Business processes partially fulfil the requested requirements

- $\quad \mathrm{N}$ (Never): Business processes do not meet the necessary requirements

- Business Process Design

In order to fixing the gaps in system, some improvements need to be made. Odoo is used as an application to implement ERP system.

\section{Procurement Cycle of RSUD XYZ}

Figure 4 shows the procurement cycle. Business process procurement consists of 6 stages. The first process is started with the inventory staff to give a document requested for procurement goods to purchase staff. Then until the fifth stage with the purchasing staff execute vendor selection, bidding, purchasing, and good receipt 
and invoice verification. And the last stage, accounting staff will process the payment execution. This process is already using the system Odoo

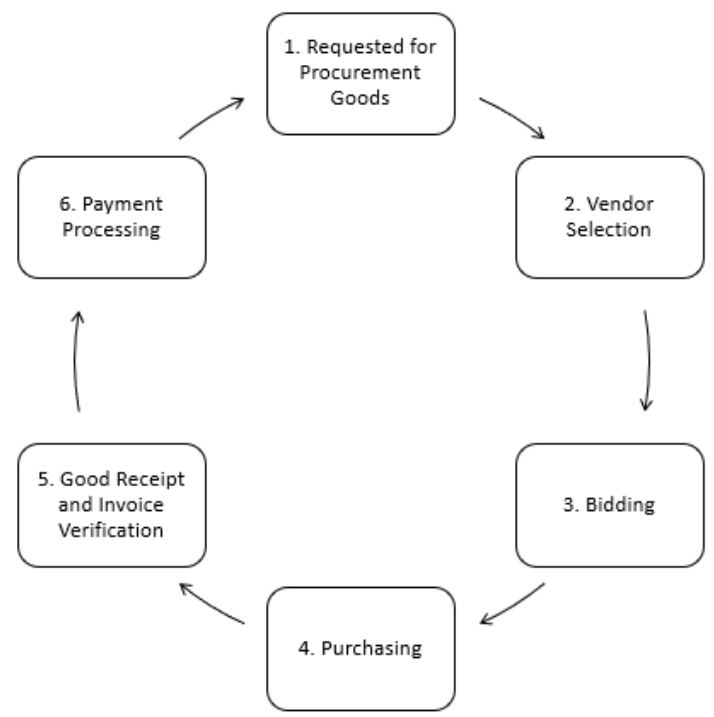

Fig. 4 - Procurement Cycle

2. Request for Procurement Goods

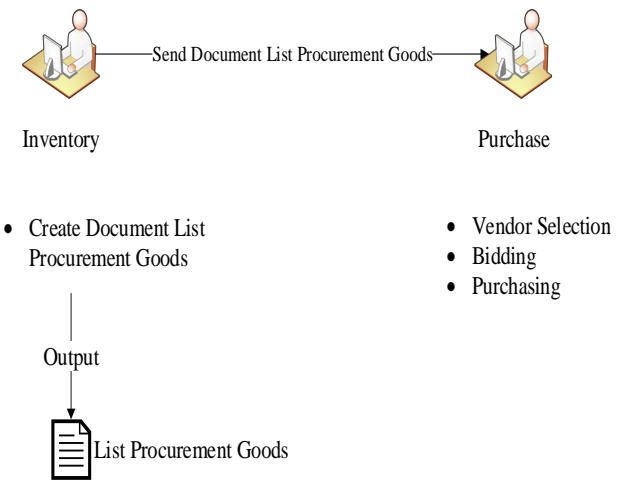

\section{Fig. 5 - Request for Procurement Goods}

Figure 5 shows the first stage of procurement. In this stage, there are two users. Inventory staff will be created document list procurement. The document contains the name of item goods, quantity, date, etc. Then Inventory staff sends a document to Purchase. Purchase staff executes vendor selection, bidding, and purchasing.

3. Vendor Selection

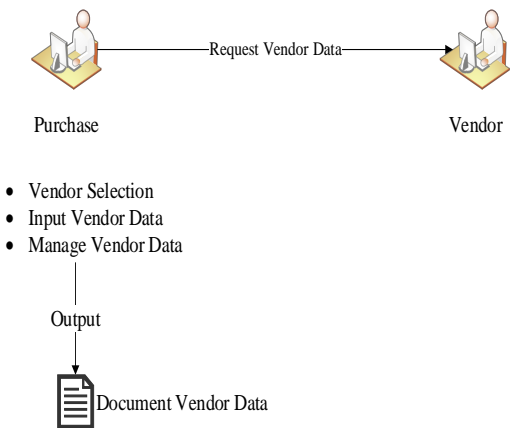

Fig. 6 - Vendor Selection Process

Figure 6 shows the second stage of procurement. In this stage, there are two users. Purchase staff executes vendor selection. When Purchase staff already select a vendor that suit with company needs, Purchase staff will request the vendor data and then input vendor data in the system. And then, Purchase staff will manage 
vendor data. The system collects information related to a vendor such as company name, address, contact, email, etc.

4. Bidding Process

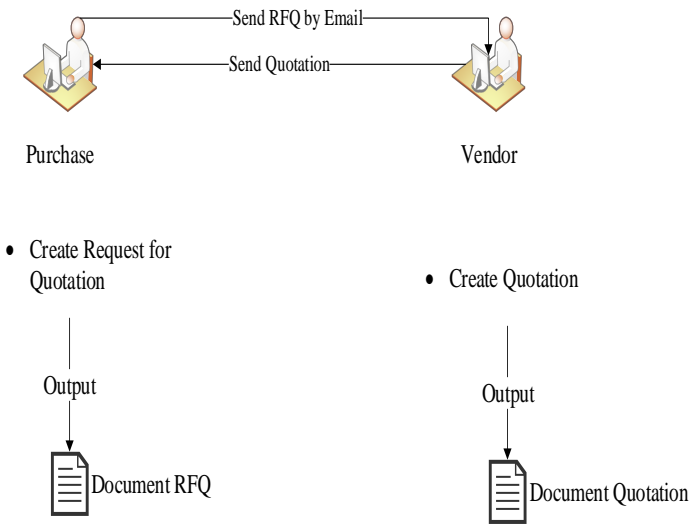

Fig. 7 - Bidding Process

Figure 7 shows the third stage of procurement. In this stage, there are two users. Purchase staff will create a request for quotation. Then send the RFQ document by email. Information gathered from this document including names of an item, quantity, and price. If the vendor rejects the RFQ, the vendor will be created a quotation with the price that vendor wants. Then send the document quotation to the vendor. If the vend or agrees, then execute converting RFQ to PO automatically. If the vendor rejects the quotation, the vendor will do a vendor selection.

5. Purchasing

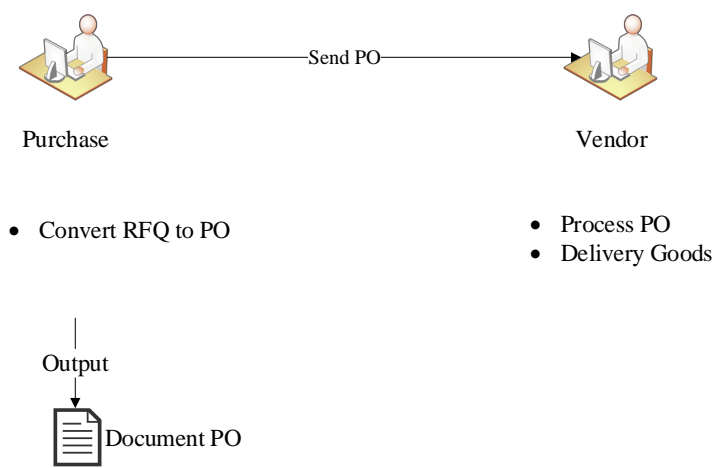

Fig. 8 - Purchasing Business Process

Figure 8 shows the fourth stage of procurement. In this stage, there are two users. After bidding, and agreeing on a price. Purchase staff will be converted RFQ to PO automatically. After those processes, the system will automatically send the purchase order to the vendor. And then the vendor will execute the purchase order and deliver goods.

6. Receiving Goods

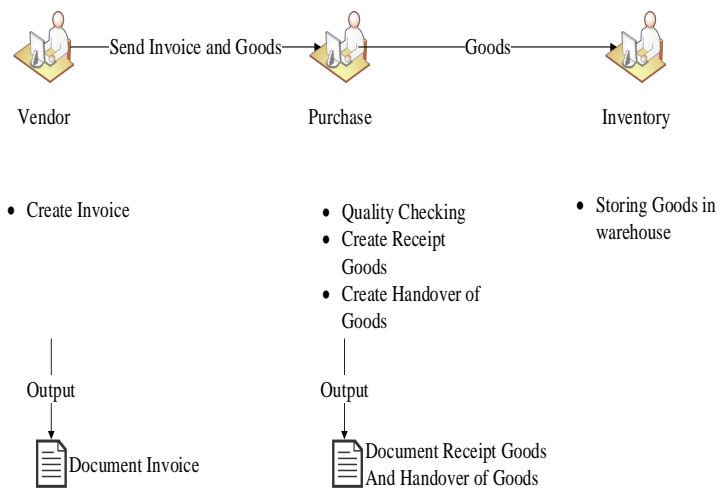

Fig. 9 - Business Process of Receiving Goods 
Figure 9 shows the fifth stage of procurement. This stage there are three users. The vendor staff will create an invoice. Then, send Invoice and goods to Purchase staff. The goods will be checked by Purchase staff. The result of Goods checked will be matched with the document purchase order and invoice. If the goods match, create a document of receipt of goods and confirm to the vendor. And then, created document handover of goods. Document handover of goods and goods will be sent to Inventory staff.

7. Payment Processing

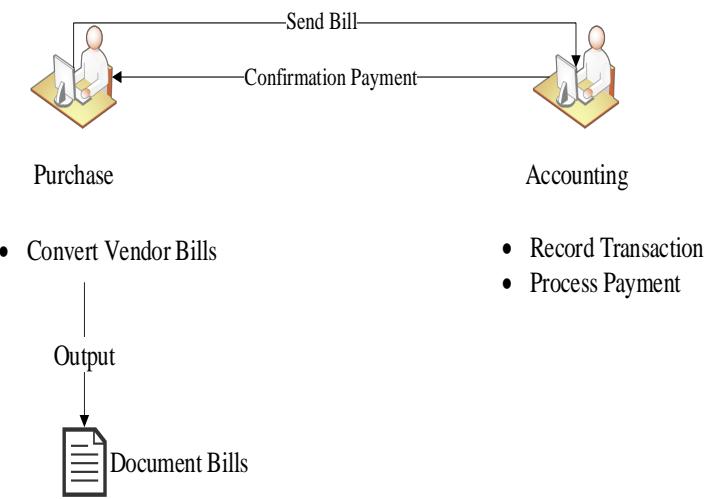

Fig. 10 - Business Process of Payment Goods

Figure 10 is the sixth stage of procurement. In this stage, there are two users. After receiving goods, the Purchase staff will be created vendor bill transactions. Then Purchase staff will send a document bill to the Accounting staff. After that, Accounting staff will record transactions and process payments. Payment status would be changed to paid automatically. After that, the Accounting staff would confirm the payment to purchase.

\section{- $\quad$ System Architecture Model}

System architecture model is designed for planning based on the basic architecture framework, this design consists of the components of a system, where this design will identify functions for each component and connectivity between components.

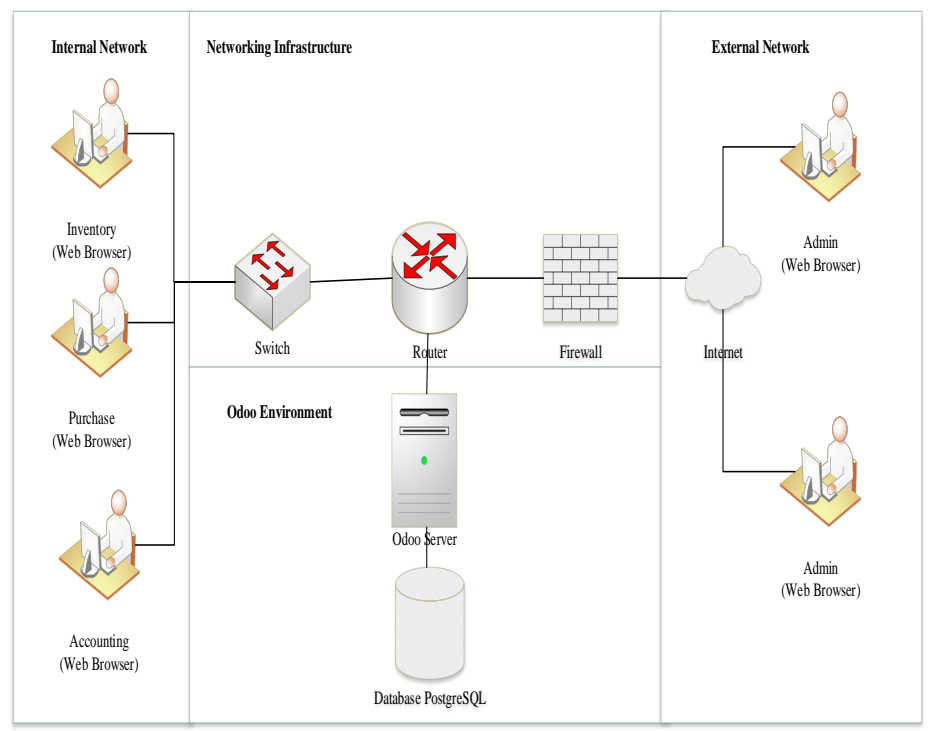

Fig. 11 - System Architecture Model

Figure 10 shows the system architecture model. The system will be designed to provide user access related to the procurement, such as inventory, purchase, and accounting. In user access, there are limitations in the system. All Odoo data are distributed in a centralized database. This design explains that internal users, namely inventory, purchase and accounting will access through Odoo's web browser and then through switches, routers, Odoo servers, and PostgreSQL databases. The PostgreSQL database is a centralized database in this design, so that all data in the RSUD will be stored in the PostgreSQL database.

At the stage of configuring user access aims to determine the limits of each user so that it regulates what features can be accessed by users who use ERP systems. Each user has a user group in accordance with the functionality in the company 
- $\quad$ Testing System

At this stage, testing the system. Tests used in this study are Stress Testing, Cross Browser Testing, and Blackbox Testing. Stress Testing is used to test the performance of the system used in the application, which aims to determine the capabilities performed by the system. Cross Browser Testing is used to see the suitability of the appearance of the application in a web browser. Blackbox Testing aims to determine the flow of integration between parts of the ERP system.

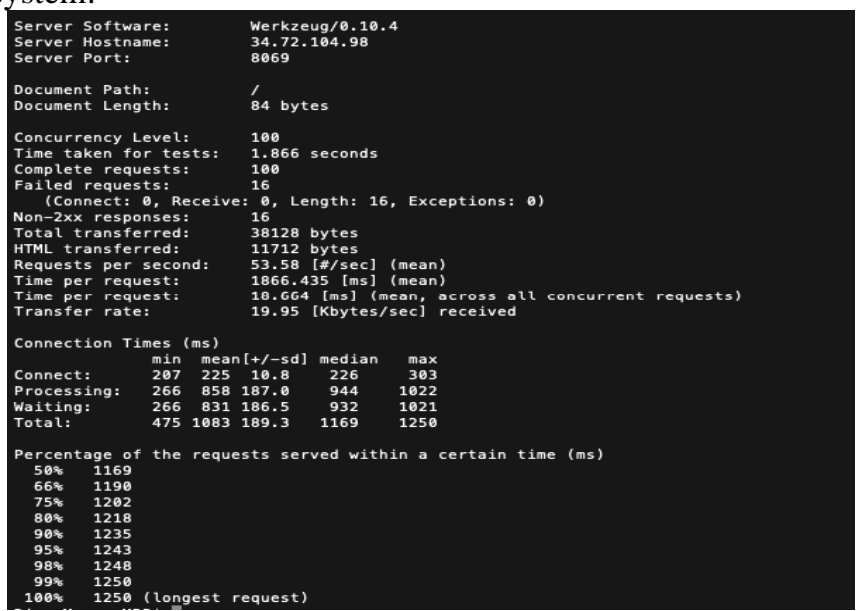

Fig. 12 - Stress Testing with n 100 and c 100

In Fig 12 the result of Stress Testing if there are 100 requests that can be given to 100 users who access the application simultaneously, then the Odoo system at Hospital can send a response for 53.58 seconds. This shows that the application can handle 100 users.

\section{CONCLUSION}

The conclusion of this research is Odoo software especially the Purchase Management Module as the solution to the purchasing activity problem in the public hospital can accommodate the needs of the organization to manage their goods, medicine and also health equipment. The development of Odoo in Public Hospital using Odoo Quickstart Methodology, through this methodology, the organization can implement the completion process on time and the costs needed can be adjusted to their budget.

With Purchase Management Module in Odoo Software, the hospital can ensure the goods, medicine and health equipment needed by the hospital to serve the patient can be provided and fulfilled on time. Besides that, the researcher also gives a recommendation to Public Hospital to attend training for the users to make the system run more effectively in the hospital and also suggesting the hospital to make sure the implementation process of the other module related to the purchasing management module was clear.

\section{Acknowledgement}

Researcher thank you the previous researcher of the related research, also special thank you to Hafida Noor Azizah, Fadhilah Dian Utami, Alif Shofa Danutirta and ERP Laboratory.

\section{References}

[1] Menteri Kesehatan Republik Indonesia. (2018). Peraturan Menteri Kesehatan Republik Indonesia. Retrieved from www.persi.or.id: https://www.persi.or.id/images/regulasi/permenkes/pmk42018.pdf

[2] Ganesh, K., Mohapatra, S., Anbuudayasankar, S. P., \& Sivakumar, P. (2014). Enterprise Resource Planning : Fundamentals of Design and Implementation. In K. Ganesh, S. Mohapatra, S. P. Anbuudayasankar, \& P. Sivakumar, Enterprise Resource Planning : Fundamentals of Design and Implementation (p. 7). New York: Springer.

[3] Zeelig, P. (2015). Implementation Methodologies for SMEs. Retrieved from docs.huihoo.com: https://docs.huihoo.com/odoo/training/reference-material/implementation-methodologies-for-smes.pdf

[4] H. A. Fatimah and R. Trisminingsih, "Analyzing Success Factors of Enterprise Resource Planning Adoption using Analytical Hierarchy Process," International Journal of Innovation in Enterprise System, vol. 2, no. 01, p. 1, 2018.

[5] S., R., \& K., K. (2018). Implementation of Odoo ERP for Business Applications. IOSR Journal of Computer Engineering, 32-39. 
[6] D. C. G. Putri, R. W. Witjaksono and M. D. Idawicaksakti, "Information System Design Based On Enterprise Resource Planning Using Account Payable Module Sap With ASAP Method In PT. Len Industri (Persero)," International Journal of Innovation in Enterprise System, vol. 2, no. 01, p. 1, 2018.

[7] Pratama, T. A. (2016). Analisis Perbandingan Free/Open Source ERP (FOS ERP) dari Aspek Arsitektur, Fungsionalitas, dan Komunitas. 13.

[8] Gajjar, M. (2017). Odoo 10 Implementation CookBook. Birmingham - Mumbai: Packt Publising Ltd.

[9] Devkota, A. (2016). Open ERP Odoo Guidebook for small and medium Enterprise. 9-26.

[10] Zahra, D. K. (2019). Perancangan Sistem ERP Manajemen Rantai Pasok Halal Untuk Industri Makanan Modul Purchase Dengan Metode Asap (Studi Kasus: Vannisa Brownies). 13.

[11] Kusmini, Satibi, \& Suryawati, S. (2016). Evaluasi Pelaksanaan E-Purchasing Obat Pada Dinas Kesehatan Kabupaten

[12] Syaer, A. A., \& Suprini. (2016). Menganalisis penerapan sistem e-procurement dalam upaya meningkatkan minat penyedia barang/jasa pemerintah pada unit layanan pengadaan Kabupaten Rotan Hulu. Seminar Nasional Teknologi Informasi dan Komunikasi, 3.

[13] World Health Organization. (2019). Health. Retrieved from www.who.int: https://www.who.int/

[14] Drechsler, A., \& Hevner, A. (2016). A Four-Cycle Model of IS Design Science Research: Capturing the Dynamic Nature of IS Artifact Design. 1-8.

[15] Odoo. (2019). Basics of the Quickstart Methodology. Retrieved from Odoo:https://www.odoo.com/documentation/user/11.0/getting_started/documentation.html 